\title{
Mercury Sensing Probes
}

\author{
Shin-Ichi OHIRA
}

\author{
Department of Chemistry, Kumamoto University, 2-39-1 Kurokami, Chuo, Kumamoto 860-8555, Japan
}

The Minamata Convention on Mercury will enter into force on August 16, 2017. ${ }^{1}$ This convention was concluded on October 19, 2013 at Kumamoto, Japan. It purposes to protect human health and environments from any anthropogenic mercury contamination. Owing to the extreme toxicity of mercury, the United States Environmental Protection Agency (EPA) established the standard for the maximum allowed level of mercury in dietary and environmental sources to be $2 \mu \mathrm{g} / \mathrm{L}$ $(10 \mathrm{nM})$. One of the important steps for achieving the purpose is to monitor mercury in the environment and living cells. Recently, colorimetric and fluorometric probe reagents for the detection of mercury have been attractively studied. Zhou et al. reported on a coumarin-based fluorescent reagent for $\mathrm{Hg}^{2+}$ detection, and applied it to develop a test paper that can detect even with naked eyes. ${ }^{2}$ Mi et al. developed a water-soluble conjugated polymer, (poly(2,5-bis(sodium-4-oxybutyrate)-1,4phenylethynylene-alt-1,4-phenyleneethynylene, PPE-OBS). ${ }^{3}$ The fluorescence of PPE-OBS was selectively quenched by $\mathrm{Hg}^{2+}$, and can be applied to detect $\mathrm{Hg}^{2+}$ with wide dynamic ranges $(60-80000 \mathrm{nM})$. Wang et al. reported fluorescent polymeric micelles to detect $\mathrm{Hg}^{2+}$ in blood serum. ${ }^{4}$ Fluorescein isothiocyanate was linked with the polymer for micelles formation, and the fluorescence was quenched by $\mathrm{Hg}^{2+}$. $\mathrm{Li}$ et al. reported rhodamine-based probe, and achieved a detection limit of $1 \mathrm{nM} .5$ Vedamalai et al. reported on a BODIPY-clickate based fluorescence probe. ${ }^{6}$ These developed compounds were applied to determine $\mathrm{Hg}^{2+}$ not only in aqueous water but also for imaging of living cells. ${ }^{5,6}$ A specific T-Hg-T mismatch on DNA was also applied to the fluorometric detection of $\mathrm{Hg}$. Zhang et al. used N-methyl mesoporphylin IX (NMM)/G-quadruplex DNA system as reporter. ${ }^{7}$ Xiang et al. also used molecular beacon and Hoechst 33258 as a reporter, and applied it to the detection of $\mathrm{Hg}^{2+}$ in soil with a detection limit of $3 \mathrm{nM}^{8}{ }^{8}$ Nanomaterials were also successively applied for $\mathrm{Hg}$ detection. Nitrogen-doped carbon dots made from citric acid with ammonia $^{9}$ or diethylenetriamine ${ }^{10}$ was developed for the fluorometric detection of $\mathrm{Hg}^{2+}$ in environmental water and imaging in living cells. Guan et al. used thiol-functionalized

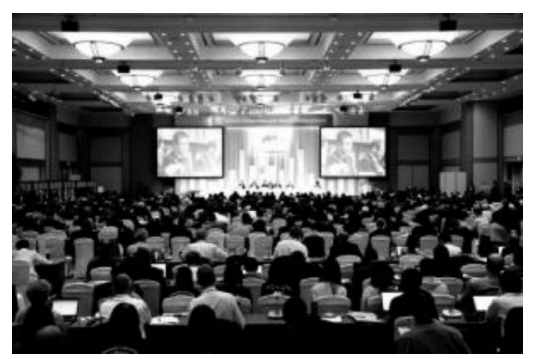

Conference of Plenipotentiaries on the Minamata Convention on Mercury, October, 2013, Kumamoto, Japan.

E-mail: ohira@kumamoto-u.ac.jp poly vinyl alcohol capped CdS quantum dots with fluorescence quenching and achieved a detection limit of $1 \mathrm{nM} .^{11}$ Meelapsom et al. reported on a red green blue (RGB) color model with silver nanoparticles and paper microfluidic devices for selective $\mathrm{Hg}^{2+}$ detection. ${ }^{12}$ Firdaus et al. reported on silver nanoparticles made from an aqueous fruit extract of water apple. ${ }^{13} \mathrm{Li}$ et al. used chicken egg white-stabilized $\mathrm{Au}$ nanoclusters that is fluorescent material to be quenched by $\mathrm{Hg}^{2+} \cdot{ }^{24}$ The $\mathrm{Au}$ nanoclusters also responded to $\mathrm{Cu}^{2+}$; however, the interference was removed by the addition of ethylenediaminetetraacetic acid (EDTA) as a masking reagent.

Mercury has been widely used as catalysts, electrodes and solvents in the world because of its special properties. Mercury detection in water, soil, atmosphere and human body will receive increased attention in the near future. Mercury sensing probes may play important roles in these situations with batch methods, the fiber-optic sensor format, ${ }^{15}$ flow injection analysis and so on.

Keywords Mercury, sensing probe

\section{References}

1. United Nations Environment Minamata Convention on Mercury, www.mercuryconvention.org.

2. H. Zhou, W. Tian, M. Jiang, P. Li, S. Zeng, W. Chen, and A. Ma, Anal. Sci., 2015, 31, 1285.

3. H. Mi, M. Guan, H. Shan, Q. Fet, Y. Huan, Z. Zhang, and G. Feng, Anal. Sci., 2016, 32, 1039.

4. H. Wang, J. Chen, Y. Hong, K. Lv, M. Yu, P. Zhang, Y. Long, and P. Yi, Anal. Sci., 2017, 33, 591.

5. D. Li, C.-Y. Li, Y.-F. Li, Z. Li, and F. Xu, Anal. Chim. Acta, 2016, 934, 218.

6. M. Vedamalai, D. Kedaria, R. Vasita, S. Moric, and I. Gupta, Dalton Trans., 2016, 45, 2700.

7. X. Zhang, B. Ding, H. Wu, J. Wang, and H. Yang, Anal. Sci., 2017, 33, 165.

8. D. Xiang, K. Zhai, Q. Sang, B. Shi, and X. Yang, Anal. Sci., 2017, 33, 275.

9. Y. Liu, M. Liao, X. He, X. Liu, X. Kou, and D. Xiao, Anal. Sci., 2015, 31, 971.

10. X. Sun, S. Yang, M. Guo, S. Ma, M. Zheng, and J. He, Anal. Sci., 2017, 33, 761.

11. X. Guan, H. Fan, Y. Zhang, D. Zhang, T. Jia, S. Lai, and Z. Lei, Anal. Sci., 2016, 32, 161.

12. R. Meelapsom, P. Jarujamrus, M. Amatatongchai, S. Chairam, C. Kulsing, and W. Shen, Talanta, 2016, 155, 193.

13. M. L. Firdaus, I. Fitriani, S. Wyantuti, Y. W. Hartati, R. Khaydarov, J. A. Mcalister, H. Obata, and T. Gamo, Anal. Sci., 2017, 33, 831.

14. X.-J. Li, J. Ling, C.-L. Han, L.-Q. Chen, Q.-E. Cao, and Z.-T. Ding, Anal. Sci., 2017, 33, 671.

15. S. V. Muginova, D. A. Myasnikova, S. G. Kazarian, and T. N. Shekhovtsova, Anal. Sci., 2017, 33, 261. 